\title{
Canine perineal hypospadias
}

\author{
[Hipospadia perineal canina] \\ L.D. Guimarães, E. Bourguignon, L.C. Santos, T.S. Duarte, E.C. Andrade, A.P.B. Borges
}

Universidade Federal de Viçosa - Viçosa, MG

\begin{abstract}
Canine hypospadias is a rare condition that can occur in male and female dogs. Affected animals may present signs of urinary incontinence, recurrent urinary tract infections, periurethral dermatitis or can remain asymptomatic. Periurethral hypospadias in a 14-week-old mongrel dog and its surgical repair are addressed.
\end{abstract}

Keywords: dog, penis, prepuce, urethra

\section{RESUMO}

Hipospadia canina é uma condição rara que pode ocorrer em cães machos e fêmeas. Animais afetados podem apresentar sinais de incontinência urinária, infecções recorrentes do trato urinário, dermatite periuretral ou podem permanecer assintomáticos. Hipospadia periuretral em cão de 14 semanas de idade, sem raça definida, e sua reparação cirúrgica são abordadas.

Palavras-chave: cão, pênis, prepúcio, uretra

\section{INTRODUCTION}

Hypospadias is a rare developmental anomaly in which the urethra opens ventral and caudal to its normal anatomic location (Memon e Mickelsen, 2004; Fossum, 2008). It occurs in both sexes (Memon e Mickelsen, 2004), whereas in males it refers to the absence of fusion of the urogenital folds, resulting in incomplete formation of the penile urethra. This anomaly is often associated with failure of fusion of the prepuce and absence or underdevelopment of the penis (Bjorling, 2007). It is classified based on the location of the urethra opening in glandular, penile, scrotal, perineal or anal (Fossum, 2008). Cryptorchidism is the most common defect associated with hypospadias (Memon e Mickelsen, 2004).

The etiology is believed to be the inadequate production of fetal androgen (Memon e Mickelsen, 2004), and the prevalence in the Boston terrier breed suggests a familial predisposition (Kruger et al., 2001; Lyle, 2003; Memon e Mickelsen, 2004; Fossum, 2008). It

Recebido em 31 de julho de 2012

Aceito em 30 de julho de 2013

E-mail: ludiegues@yahoo.com.br can be diagnosed during the first puppy examination or the owner might report the output of urine from an unusual orifice (Bjorling, 2007). Affected dogs may be asymptomatic or develop clinical signs of urinary incontinence, periurethral dermatitis or recurrent urinary tract infection (Fossum, 2008).

The abnormal urethral opening near penile tip may not require surgery, in other cases the reconstruction is recommended (Lyle, 2003; Fossum, 2008). The scrotal or perineal urethrostomy combined with castration and removal of the prepuce and penile vestigial tissues aims esthetics or functional correction (Kruger et al., 2001).

The aim of this paper is to report a case of perineal hypospadias in a male puppy.

\section{CASE REPORT}

A 14-week-old, intact, male mongrel dog was presented to the Federal University of Viçosa for a surgical correction of his congenital 
abnormalities. The owner noticed the defect in the penile conformation shortly after birth and also the presence of an orifice, ventral to the anus where urine was expelled. The animal had urine control and showed no signs of stranguria.

On physical examination there was an incomplete fusion of the distal urethra and the presence of a vestigial penis without the prepuce cover and with no urethral opening. The urethral opening was detected ventral to the anus. Both testicles were located in the inguinal area and the scrotum was absent (Figure 1). There were no uremic dermatological signs. In addition to congenital defects of the reproductive organs the animal had only two of the coccygeal vertebrae. The complete blood count and serum biochemical profile were within normal limits.

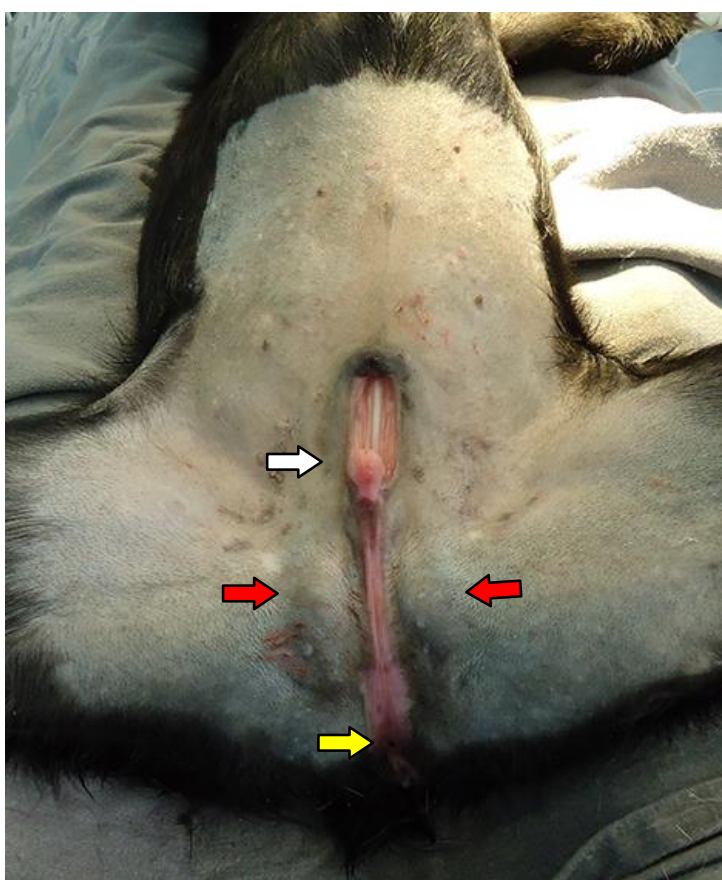

Figure 1. Perineal hypospadia in a male mongrel dog. Image shows dog in dorsal recumbence, cranial is the vestigial penis (white arrow). Testicles can be appreciated in the inguinal area (red arrows). A small orifice ventral to the anus indicated by the yellow arrow is the urethral meatus.

Surgical correction was indicated because of the possibility of penile irritation and to improve esthetics. The amputation of the vestigial penis was performed by the dissection and removal of adjacent tissues (Figure 2). The subcutaneous tissue was reduced using a 3.0 catgut and a 3.0 nylon suture using a simple separate pattern (Figure 3). The existing urinary meatus was maintained. Castration was not performed. The stitches were removed within 10 days; the wound was completely healed and the owner reported normal voiding function.

This case report was certified by the Comissão de Ética para Uso de Animais da Universidade Federal de Viçosa (CEUA/UFV) (Ethics Committee for the use of animals).

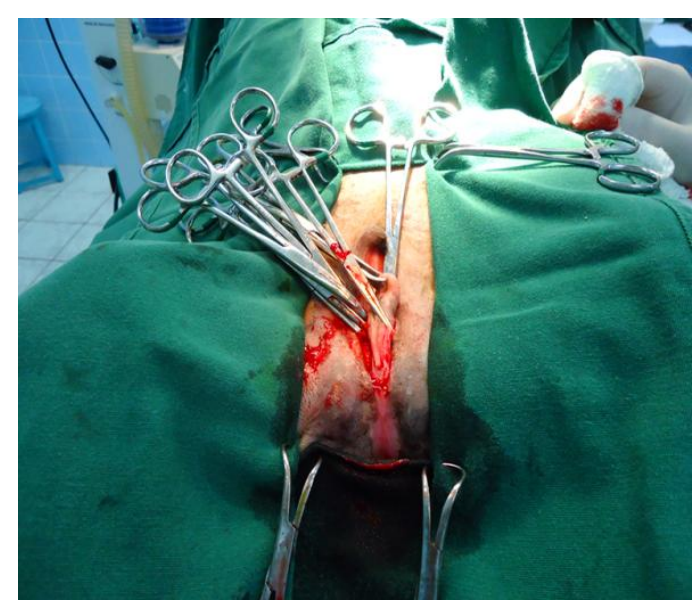

Figure 2. Surgical procedure. Amputation of the vestigial penis by the dissection and removal of adjacent tissues.

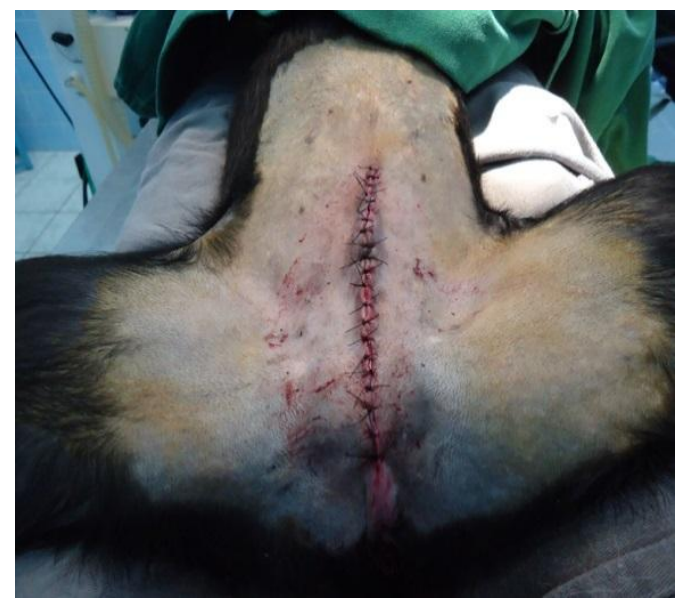

Figure 3. End of the surgical procedure showing a simple separate pattern suture. 


\section{DISCUSSION}

Hypospadias is rare, so there are few reports in the literature. In Brazil there was only one case report found, of an English Bulldog puppy, male, diagnosed at birth with hypospadias and complete absence of coccygeal vertebrae (Angeli et al., 2007). In this case, however, surgery was not performed due to the young age, only two months old puppy. The literature reports the possibility of other congenital defects associated with hypospadias, but no reports of hypospadias associated with absence of coccygeal vertebrae were found which interestingly is present in these two Brazilian cases. Because it was a large breed dog, surgery could be performed easily in a puppy only three months old.

Ectopic testes are more susceptible to torsion and neoplasia. Cryptorchid dogs have 13.6 times greater risk of testicular tumors than normal dogs. All mentioned factors may justify prophylactic removal of undescended testes (Harry, 2007). In the present case, castration was postponed because the animal has not yet completed its development and gonadal hormones are needed to do so.

Recently a surgical technique for the creation of a urethral conduit was described using a preputial flap in a Doberman Pinscher with severe perineal hypospadias. Successful transfer of a perineal urethral meatus located to a more anatomically normal location was achieved with a preputial flap. The procedure was performed to aid control of recurrent urinary tract infections after anal and urethral separation in a dog with imperforate anus, urethrorectal fistula, and proximal perineal hypospadias (Cashmore e Ladlow, 2010). Due to the severe condition of the animal, more drastic surgical urethral reconstruction was held. In the present case the animal did not show any alteration, such as periurethral dermatitis or dysuria justifying the opening of a new urethral meatus, the surgery had only an esthetic purpose.

Adelsberger e Smeak (2009) describe the corrective surgery in a Boston Terrier which was followed by a period of two years after surgery. Repeated urinary infections are reported to be very common in cases of hypospadias. In this report although the animal did not show any sign of urinary infection, the owner was alerted to the fact of its occurrence due to the absence of preputial protection which can lead to contamination from the anus. The owner was advised to maintain the area of the urethral opening clean and also to return for future castration, when the animal completes eight months of age. Unfortunately, the owner did not return and could not be contacted to follow up the case.

\section{CONCLUSION}

To our knowledge this case is very important because hypospadia is a rare condition and there were not many reported cases to date, especially in Brazil. Also it reports a successful surgical approach to hypospadias.

\section{ACKNOWLEDGEMENTS}

The authors wish to thank FAPEMIG for the financial support.

\section{REFERENCES}

ADELSBERGER, M.E; SMEAK, D.D. Repair of extensive perineal hypospadias in a Boston terrier using tabularized incised plate urethroplasty. The Canad. Vet. J., v.50, p. 937942, 2009.

ANGELI, A.L.; ROCHA, T.M.M.; MAIA, R. et al. Hipospadia perineal em cão da raça buldogue inglês: primeiro relato. Acta Scient. Vet., 35 (Supl 2), p. 591-592, 2007.

BJORLING, D.E. Uretra. In: SLATTER, D. Manual de cirurgia de pequenos animais. São Paulo: Manole, 2007. cap.112, p.1640.

CASHMORE, R.G.; LADLOW, J.F. Creation of a urethral conduit from a preputial indirect flap in a dog with perineal hypospadias. Vet. Surg., v.39, p.14-20, 2010.

FOSSUM, T.W. Cirurgia dos sistemas reprodutivo e genital. In: FOSSUM, T.W. Cirurgia de pequenos animais. São Paulo: Elsevier Editora, 2008. cap.26, p.762-764.

HARRY, W.B. Testículos e Epidídimos. In: SLATTER, D. Manual de cirurgia de pequenos animais. São Paulo: Manole, 2007. cap.102, p.1524. 
KRUGER, J.M.; OSBORNE，C.A.; LULICH, J.P. et al. The urinary system. In: HOSKINS, J.D. Veterinary pediatrics: dogs and cats from birth to six months. Philadelphia: Saunders, 2001. cap.17, p.388.

LYLE, S.K. Disorders of sexual development. In: Kustritz, M.V.R. Small animal theriogenology. USA: Elsevier Science, 2003. chap.1, p.1-31.
MEMON, M.A.; MICKELSEN, W.D. Distúrbios hereditários e congênitos dos sistemas reprodutivos do macho e da fêmea. In: ETTINGER, S.J; FELDMAN, E.C. Tratado de medicina interna veterinária doenças do cão $e$ do gato. São Paulo: Guanabara Koogan, 2004. cap.165, p.1669. 